\title{
Fractionation, Characterization and Speciation of Lead in the Industrially Polluted Soils of Tejgaon Area of Bangladesh and Lead Pollution of Associated Plants and Water
}

\author{
M. N. Mondol*, A. S. Chamon, B. Faiz, M. H. Rahman and S. F. Elahi \\ Department of Soil, Water and Environment, University of Dhaka, Dhaka-1000, Bangladesh.
}

\begin{abstract}
The Tejgaon industrial area is located within the Dhaka Municipality area and about $5 \mathrm{~km}$ north of the city centre. At Tejgaon soil pH was around neutrality (mean 6.73) although the minimum value was 5.3 and the maximum 7.6. High buffering capacity resulting from high soil organic matter content (4.87-11.55\%) probably influenced soil $\mathrm{pH}$ to a neutral value. Electrical conductivity $(\mathrm{EC})(25-551 \mu \mathrm{S})$, organic matter $(\mathrm{OM})(4.87-11.55 \%)$ and nitrogen $(\mathrm{N})$ contents were also influenced by the industrial wastes and effluents of the factories. The average $\mathrm{Pb}$ concentrations $(\mathrm{mg} / \mathrm{kg})$ in different soil fractions were 7.80, 21.85, 56.15 and 130.29 and 11.42, 20.27, 40.33 and 95.08 in water-soluble, $\mathrm{NH}_{4} \mathrm{OAc}$ extractable, DTPA ( Dietheline-Triamine-Penta-Acetic acid) extractable and total fractions during dry (January) and rainy seasons (September) respectively. Comparing 1st (rainy season) and 2nd (dry season) sampling data, Pb concentrations in different soil fractions were higher in the 2 nd sampling data. Concentration of total $\mathrm{Pb}$ in soils during 1 st sampling were found above the natural background level with few exceptions. Only $4 \%$ of total $\mathrm{Pb}\left(=20 \mathrm{mg} \mathrm{kg}^{-1}\right)$ samples were in the normal range during wet season. Lead concentration in the group of tolerable level was $58 \%\left(>20-\leq=100 \mathrm{mg} \mathrm{kg}^{-1}\right)$ and $38 \%\left(\geq=100 \mathrm{mg} \mathrm{kg}^{-1}\right)$ were found in the group of in excess of tolerable level during 1st sampling. On the other hand $62.5 \%\left(\geq=100 \mathrm{mg} \mathrm{kg}^{-1}\right)$ were found in the group of in excess of tolerable level $\left(0.01 \mathrm{mg} \mathrm{kg}{ }^{-1} \mathrm{~Pb}\right)$ during dry season. In case of water samples, total $\mathrm{Pb}$ concentration in the rainy season, all samples were found in the group of in excess of tolerable level during 1st sampling. Plant samples were found to contain untolerable total $\mathrm{Pb}\left(>20 \mathrm{mg} \mathrm{kg}^{-1}\right)$ during rainy and dry seasons, respectively.
\end{abstract}

Key words: Speciation, Tejgaon soil, Industrial area, Lead.

\section{Introduction}

The presence of heavy metals in soil raises serious concern about the adverse environmental impact as a result of excessive waste and effluent application to agricultural lands. High and excessive accumulation of heavy metals in soil and other media may eventually contaminate both human and animal food chain (He et al., 1992; Iwegbue et al., 2007). Because of this, many countries in the world have established specific guidelines and standards for application of wastes and effluents in agricultural lands. However, these guidelines are lacking in most developing countries. These guidelines, which are generally based on phytotoxic effects and limited to plant uptake studies normally specify the maximum allowable total metal concentration and exhibit considerable variation.

An appreciation of the effect of heavy metals in soil and water on crops can only be attained from precise knowledge of the heavy metal speciation and the response to plant species. In addition, speciation will determine metal mobility and hence potential contamination of ground water following industrial waste application. Although speciation schemes to examine the solid and solution phase of wastes and waste amended soils are subject to analytical limitations. Despite uncertainties resulting from the selectivity of the various extractants and possible problem due to redistribution and re-adsorption phenomena, procedures provide qualitative information on forms, association, bioavailability, their potential effects and guidelines for land application.

Bangladesh has at present about 30,000 large and small industrial units, 1. They are discharging their wastes and effluents in the natural systems in most cases without any treatment and thereby cause environmental pollution especially due to heavy metals and organic toxins. The hazardous

\footnotetext{
* Corresponding author: E-mail: mondol-bangladesh@hotmail.com
} 
wastes and effluents are generally discharged in low-lying areas along the road sides or in the vicinity of the industrial installations. Besides, the uneducated farmers are randomly using fertilizers and pesticides in agricultural lands. The heavy metals discharged from industries in Bangladesh are cadmium, lead, chromium, mercury, zinc, arsenic and in few cases copper and manganese. The industries like tannery, paper and pulps, textiles, carbides, pharmaceuticals, pesticides, distilleries etc. discharge heavy metals with their effluents and wastes.

Trace metal composition of soil varies widely depending on the sources, industrial waste type (He et al., 1992) and geographical location (Krogmann, 1999). The levels of heavy metals in municipal solid waste have been reported for many countries in the world by several authors (Watanable and Kurihara, 1982; Sridhar and Bammeke, 1986; He et al., 1992; Krogmann, 1999; Koivula et al., 2000). Trace metals can exist in a variety of forms in soil. These forms include (i) water soluble, (ii) exchangeable, (iii) linked to organic substances, (iv) occluded or co-precipitated with oxides, carbonates and phosphates, or other secondary minerals and (v) ions in the crystalline lattices of the primary minerals (Emmerich et al., 1982; Lake et al., 1984; Petruzzelli, 1989; He et al., 1992; Iwegbue et al., 2006b,c). The first three chemical forms are considered to be balanced among themselves; this equilibrium is influenced by $\mathrm{pH}$ and the concentrations of metals and ligands. The metals present in these forms are considered to be most available forms for plant nutrition, each successive form representing less availability (Petruzzelli, 1989; Iwegbue et al., 2006b).

The distribution of metals between the specific forms varies widely according to the individual metal and the characteristics of the wastes. These parameters include $\mathrm{pH}$, temperature, oxidation-reduction potential and the presence of complexing ligands.

Total trace metal composition of soil is of little importance in determining its uptake by plants and consequently, in contaminating the food chain since the different forms have different mobilities, bioavailabilities and environmental contamination potential. It is more important to know the distribution of each trace metals in the different forms, rather than just the total content (Lake et al., 1984; Petruzzelli, 1989). Various techniques used to estimate heavy metal distribution in soils, and sewage sludge have been adopted for fractiona- tion of heavy metals in soils. There are two basic techniques. These techniques include (i) physical fractionation based on particle size and density, and (ii) chemical extraction based on selective dissolution of trace metals in different reagents.

In order to asses the speciation or binding forms of heavy metals in solid materials, different analytical procedures involving successive extractions have been developed. These procedures are based on the assumption that the following species of heavy metals exist in soils (Bruemmer et al., 1986):

1. Water-soluble (i.e. in the soil solution)

2. Exchangeable

3. Organically bound

4. Occluded in iron and manganese oxides

5. Definite compounds (e.g. heavy metal carbonates, phosphates, sulphides)

6. Bound in silicate structure (i.e. the residual fraction)

The heavy metals in the soluble fraction can be determined in the saturation extract of soil samples or by extracting soil material with deionized water at a certain ratio (Horak, 1979; Sposito at al., 1982).

In the present research, sequential extraction methods were frequently used to characterize and predict the mobility and bioavailability of heavy metals in soils. The extractants commonly used included deionized water $\left(\mathrm{H}_{2} \mathrm{O}\right)$, ammonium acetate $\left(\mathrm{NH}_{4} \mathrm{OAc}\right)$, potassium chloride $(\mathrm{KCl})$, diethylene-triamine-penta-acetic acid (DTPA), and hydrochloric:nitric acid mixture called aqua regia $(\mathrm{HCl}: \mathrm{HNO} 3=3: 1)$. Each extractant was targeted on a single form of each metal, for example, $\mathrm{H}_{2} \mathrm{O}$ for soluble species, NH4OAc for exchangeable species, DTPA for plant available species and aqua regia for total, noncrystalline form of each metal species (Lake et al., 1984; He et al., 1992). During the course of the present research, soils, plant samples and water samples were collected and analyzed by various independent extractant for characterization of the lead $(\mathrm{Pb})$ species in soils and their subsequent concentration into plants and water.

\section{Material and Methods}

\section{Description of the sampling areas}

The study area consisted of two distinct areas. One was the lagoon bordering Tejgaon industrial area. This area receives 
the drainage residue of the industrial area, Gulshan model town, Niketan Housing Society, Begunbari and other adjoining residential and slum areas including numerous classified/unclassified industries. The other consisted of the canal which receives the inflow from the lagoon and drains into Balu river. In the rainy season the pollution remains minimum because of heavy rainfall; most of the suspended materials, which are not complexed and precipitated with soil, organic matter and other compounds, are flushed out through the canal into the adjoining vast flood zone. The soil and water pollution load increase when the rainy season is over.
The main focus of the study was Tejgaon industrial area which is located within the Dhaka Municipality area and about $5 \mathrm{~km}$ north of the city centre. The effluents from many diverse industries in Tejgaon industrial area flow into a lagoon where the residue settle into a thick muck. It overflows through a sluice gate at Rampura into a channel which flows east for about $10 \mathrm{~km}$ to Balu river which in turn flows into Sitalakhya river. The whole area is really a flood drainage zone which was originally connected to the Buriganga river on the west of Hazaribagh through a canal passing through Jhikatala, Dhanmondi, Kalabagan, and Hatir

Table I: Identity of different samples with sampling locations. Distances of sampling locations from source of pollution increased according to sample location number

\begin{tabular}{|c|c|c|c|c|c|c|}
\hline Location & Location Name & Longitude, & Latitude, & & mples $T_{y}$ & ype \\
\hline 1 & Begun bari. Lal Tanki & $23^{\circ} 45.7$ & $90^{\circ} 24.5$ & Soil & Water & Grass \\
\hline 2 & Boubazar & $23^{\circ} 45.8$ & $90^{\circ} 24.6$ & Soil & Water & Bean leaf \\
\hline 3 & Gulshan shooting club (G S C) & $23^{\circ} 46.0$ & $90^{\circ} 24.7$ & Soil & Water & Grass \\
\hline 4 & Back side of Arong & $23^{\circ} 46.2$ & $90^{\circ} 24.8$ & Soil & Water & Grass \\
\hline 5 & Iron Bridge & $23^{\circ} 46.3$ & $90^{\circ} 24.9$ & Soil & Water & Grass \\
\hline 6 & Flood plain & $23^{\circ} 46.2$ & $90^{\circ} 25.0$ & Soil & Water & Grass \\
\hline 7 & Flood plain & $23^{\circ} 46.1$ & $90^{\circ} 25.1$ & Soil & - & Grass \\
\hline 8 & Rampura Bridge & $23^{\circ} 46.1$ & $90^{\circ} 25.4$ & Soil & Water & Grass \\
\hline 9 & Ullan & $23^{\circ} 46.1$ & $90^{\circ} 24.9$ & Soil & Water & Grass \\
\hline 10 & Mahanagar Project & $23^{\circ} 45.9$ & $90^{\circ} 24.8$ & Soil & Water & Grass \\
\hline 11 & Madhubag & $23^{\circ} 45.6$ & $90^{\circ} 24.6$ & - & Water & - \\
\hline 12 & Ha-Meem Garments & $23^{\circ} 45.7$ & $90^{\circ} 24.4$ & Soil & Water & - \\
\hline 13 & Nasirabad & $23^{\circ} 45.7$ & $90^{\circ} 27.8$ & - & Water & - \\
\hline 14 & Nasirabad ghat & $23^{\circ} 45.7$ & $90^{\circ} 27.8$ & Soil & Water & Water hyacinth \\
\hline 15 & Nasirabad & $23^{\circ} 45.7$ & $90^{\circ} 27.9$ & Soil & Water & Water hyacinth \\
\hline 16 & Nasirabad & $23^{\circ} 45.7$ & $90^{\circ} 28.1$ & Soil & Water & Bean leaf \\
\hline 17 & Guronagar bottala & $23^{\circ} 45.7$ & $90^{\circ} 28.4$ & Soil & Water & Kalmi \\
\hline 18 & Guronagar & $23^{\circ} 45.6$ & $90^{\circ} 28.7$ & Soil & Water & Kalmi \\
\hline 19 & Balu river & $23^{\circ} 45.6$ & $90^{\circ} 28.7$ & Soil & Water & Water hyacinth \\
\hline 20 & Nalchata ghat & $23^{\circ} 46.6$ & $90^{\circ} 28.9$ & Soil & Water & Kalmi \\
\hline 21 & Nalchata & $23^{\circ} 45.5$ & $90^{\circ} 28.9$ & Soil & Water & Kalmi \\
\hline 22 & Balu river & $23^{\circ} 45.55$ & $90^{\circ} 29.0$ & - & Water & Kalmi \\
\hline 23 & Dasher Kandi & $23^{\circ} 45.9$ & $90^{\circ} 27.8$ & Soil & Water & Water hyacinth \\
\hline 24 & Trimohini & $23^{\circ} 45.6$ & $90^{\circ} 27.5$ & Soil & Water & Water hyacinth \\
\hline 25 & Trimohini & $23^{\circ} 45.6$ & $90^{\circ} 27.2$ & Soil & Water & Water hyacinth \\
\hline 26 & Aongargora Meradia & $23^{\circ} 46.6$ & $90^{\circ} 26.8$ & Soil & Water & Water hyacinth \\
\hline 27 & Meradia & $23^{\circ} 45.7$ & $90^{\circ} 26.5$ & Soil & Water & Kalmi \\
\hline 28 & Aftab nagar & $23^{\circ} 45.8$ & $90^{\circ} 26.2$ & & Water & Water hyacinth \\
\hline 29 & Banashere & $23^{\circ} 45.8$ & $90^{\circ} 25.9$ & & Water & Water hyacinth \\
\hline 30 & Rampura Bridge & $23^{\circ} 46.0$ & $90^{\circ} 25.6$ & & Water & Water hyacinth \\
\hline
\end{tabular}


Jheel into Balu river. The canal between Jhikatala and Dhanmondi was closed during the middle of the last century. Overflowing rainwater used to discharge through this canal. Dhanmondi-Kalabagan portion was closed about 20 years ago. Other parts of the vast flood drainage zone are fast being filled up to cater for the development of Dhaka city. The common agricultural crop is rice with substantial amount of various vegetables like chilli, capsicum, carrot, cauliflower, cabbage, corriander, water hyacinth, and tomato. There are abundance of water hyacinth and natural grasses inside the embankment, which are used as fodder for domestic animals. transported to laboratory and preserved at $+4^{\circ} \mathrm{C}$ for processing next day.

\section{Soils}

The soil samples were collected from 0-15 cm depth. Water soluble, $\mathrm{NH}_{4} \mathrm{OAC}$ extractable, DTPA extractable fractions were analyzed and moisture contents of samples were determined on the next day. Rest of the samples were air dried and ground to pass through 2-mm sieve for subsequent physical and chemical analysis.

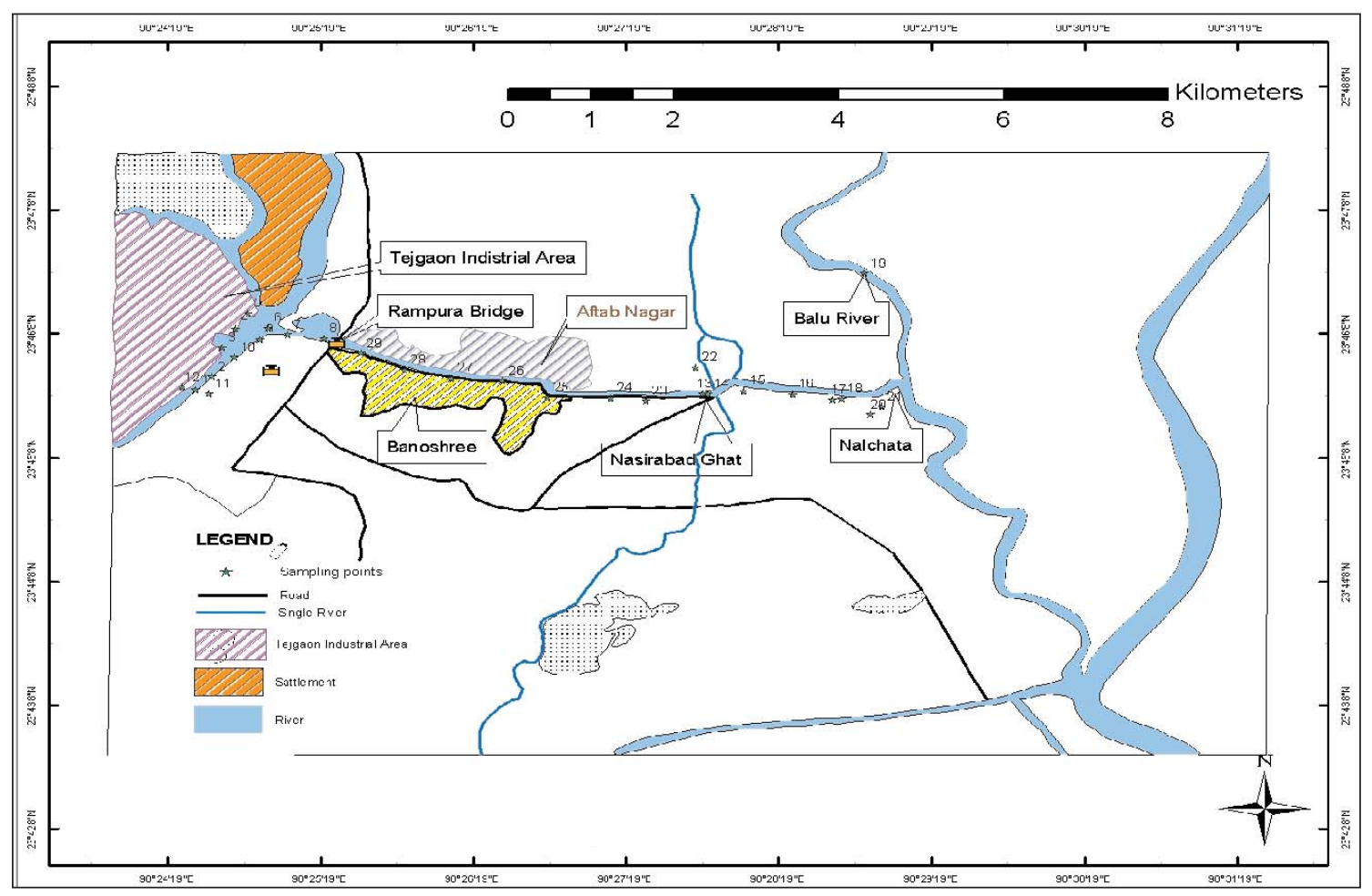

Fig. 1: Location of Sampling Sites During Dry and wet Season

\section{Sample collection and preservation}

Soil samples were collected from the study area on two different dates, September, 2006 (wet season) and January, 2007 (dry season). Aerial photographs were downloaded from Google Earth website. The sampling sites were of georeferenced with GPS (Global Positional System) and marked on the map (Figure 1). The location of sampling sites are given in Table I. All samples were collected fresh from the field in required amounts, wrapped in polyethylene bags and

\section{Metal extraction and determination}

i. Water soluble : Soil samples were extracted with deionized water at a soil:water ratio of $1: 10$ according to Sparks, et al. (2001).

ii. $\mathrm{NH}_{4} \mathrm{OAc}$ extractable: Soil samples were extracted with $\mathrm{NH}_{4} \mathrm{OAc}$ at soil: $\mathrm{NH}_{4} \mathrm{OAc}$ solution ratio of 1:10 according to Sparks, et al. (2001).

iii. DTPA extractable: Soil samples were extracted with 
DTPA solution at soil:DTPA solution ratio of 1:2 according to Sparks, et al. (2001).

iv. Total (non-crystalline fraction): Soil samples were digested with aqua regia $\left(\mathrm{HCl}: \mathrm{HNO}_{3}\right)$ according to Blum, et al. (1996).

\section{Plants}

All samples were air dried before oven drying at $70^{\circ} \mathrm{C}$ and ground to powder to pass through a 2-mm sieve for chemical analysis. After digestion the clear solution was adjusted to a volume of $100 \mathrm{~mL}$ with distilled deionized water.

\section{Digestion with $\mathrm{HNO}_{3}-\mathrm{HClO}_{4}$}

One gm of finely ground plant sample was weighed into a $100 \mathrm{~mL}$ Kjeldahl flask and digested with $10 \mathrm{~mL}$ conc. $\mathrm{HNO}_{3}$ and $2 \mathrm{~mL}$ conc. $\mathrm{HClO}_{4}$.

\section{Water}

Water samples $(500 \mathrm{~mL})$ were collected from each site in deionized polyethylene bottles fitted with liquid-tight stopper from source water. The samples were immediately acidified with $4 \mathrm{~mL}$ of concentrated hydrochloric acid per litre and analyzed within 7 days of collection.

$\mathrm{Pb}$ in the extracted solutions, plant and water samples were determined by atomic absorption spectrophotometer in the Centre for Advanced Research on Physical, Chemical, Biological and Pharmaceutical Sciences, Dhaka University of Bangladesh.

\section{Statistical analysis}

At Tejgaon soil $\mathrm{pH}$ was around neutrality (mean 6.73) although the minimum value was 5.3 and the maximum 7.6. High buffering capacity resulting from high soil organic matter content (4.87-11.55\%) probably influenced soil $\mathrm{pH}$ to a neutral value. Electrical conductivity (EC) $(25-551 \mu \mathrm{S})$, organic matter $(\mathrm{OM})(4.87-11.55 \%)$ and Nitrogen $(\mathrm{N})$ contents were also influenced by the industrial wastes and effluents of the factories.

The water soluble fraction is certainly the most biologically active. The high toxicity potential of this fraction is proven by the higher sensitivity exhibited by plants grown in hydroponic media. The water soluble fraction has highest potential of contamination of food chain, surface water and groundwater (Leita and De Nobili, 1991; He et al., 1992).

\section{1st sampling during wet season}

$\mathrm{The} \mathrm{Pb}$ concentration ranges in different extraction fractions of the 1st collected samples, were found to be 1.84-43.35, 2.85-55.0, 6.1-109.91 and 11.0-213.0 $\mathrm{mg} \mathrm{kg}^{-1} \mathrm{~Pb}$ in watersoluble, $\mathrm{NH}_{4} \mathrm{OAc}$ extractable, DTPA extractable and total fractions respectively (Table II).

The $\mathrm{Pb}$ concentration decreased from location 1 to successive locations in all respect but total $\mathrm{Pb}$ concentration at sampling points 1 to 12 were found variable and in some cases above the tolerable limit value of $100 \mathrm{mg} \mathrm{kg}^{-1}$ (Kloke, 1980).

Water soluble $\mathrm{Pb}$ concentrations in different sampling points were significantly different from each. The lowest concentration of water soluble lead was found in the sampling point 14 and 18. On the other hand the highest concentration of water soluble $\mathrm{Pb}$ was found in the sampling point 1 i.e. at the source point.

$\mathrm{NH}_{4} \mathrm{OAc}$ and DTPA extractable $\mathrm{Pb}$ concentration at different sampling points were significantly different from each other. The lowest concentration of $\mathrm{NH}_{4} \mathrm{OAc}$ extractable $\mathrm{Pb}$ was found at the sampling point 14 and the highest was found in the sampling point 1 i.e. at the source point. The lowest concentration of DTPA extractable Pb was found in the sampling point 14 and the highest was found in the sampling point 1 i.e. at the source point.

In case of total $\mathrm{Pb}$ concentration in soil, the lowest value was at location 14 and the highest was in the sampling point 1 i.e. at the source point, which was above the tolerable limit value (Kloke, 1980). Total lead concentration in 24 sampling points differed significantly from each other with some exceptions (Table II).

\section{2nd sampling during dry season}

In the 2nd collected samples during dry season, the $\mathrm{Pb}$ concentration ranges in different fractions of extraction were found to be 3.21-27.48, 7.30-47.18, 16.26-101.61 and 59.83$222.2 \mathrm{mg} \mathrm{kg}-1 \mathrm{~Pb}$ in water-soluble, NH4OAc extractable, DTPA extractable and total fractions respectively (Table III). The average $\mathrm{Pb}$ concentration in different soil fractions were 7.80, 21.85, 56.15 and $130.29 \mathrm{mg} \mathrm{kg}-1 \mathrm{~Pb}$ in water-soluble, $\mathrm{NH}_{4} \mathrm{OAc}$ extractable, DTPA extractable and total fractions respectively (Table III). Comparing wet and dry season sampling data, mean $\mathrm{Pb}$ concentrations in different soil fractions were higher in the 2nd sampling data with the exception of 
Table II: Concentration of lead in soils with different extractions during rainy season, 1 st sampling (in $\mathbf{m g ~ k g}^{-1}$ )

\begin{tabular}{c|c|c|c|c|c|c}
\hline Location & $\begin{array}{c}\text { Longitude, } \\
\text { North }\end{array}$ & $\begin{array}{c}\text { Latitude, } \\
\text { East }\end{array}$ & $\begin{array}{c}\text { Water } \\
\text { soluble }\end{array}$ & $\begin{array}{c}\text { NH4OAc } \\
\text { Extractable }\end{array}$ & DTPA & $\begin{array}{c}\text { Total } \\
\text { Extractable }\end{array}$ \\
\hline 1 & $23^{\circ} 45.7$ & $90^{\circ} 24.5$ & $43.35 \mathrm{w}$ & $55.0 \mathrm{n}$ & $109.91 \mathrm{r}$ & $213.00 \mathrm{u}$ \\
2 & $23^{\circ} 45.8$ & $90^{\circ} 24.6$ & $11.58 \mathrm{o}$ & $25.76 \mathrm{jk}$ & $45.00 \mathrm{k}$ & $138.00 \mathrm{q}$ \\
3 & $23^{\circ} 46.0$ & $90^{\circ} 24.7$ & $21.79 \mathrm{u}$ & $41.40 \mathrm{~m}$ & $76.00 \mathrm{q}$ & $154.00 \mathrm{t}$ \\
4 & $23^{\circ} 46.2$ & $90^{\circ} 24.8$ & $12.79 \mathrm{q}$ & $22.66 \mathrm{ij}$ & $38.00 \mathrm{i}$ & $98.00 \mathrm{k}$ \\
5 & $23^{\circ} 46.3$ & $90^{\circ} 24.9$ & $14.35 \mathrm{r}$ & $32.19 \mathrm{l}$ & $49.00 \mathrm{l}$ & $103.50 \mathrm{~m}$ \\
6 & $23^{\circ} 46.2$ & $90^{\circ} 25.0$ & $17.06 \mathrm{~s}$ & $33.80 \mathrm{l}$ & $54.00 \mathrm{~m}$ & $130.00 \mathrm{o}$ \\
7 & $23^{\circ} 46.1$ & $90^{\circ} 25.1$ & $17.92 \mathrm{t}$ & $24.67 \mathrm{jk}$ & $55.00 \mathrm{n}$ & $123.00 \mathrm{n}$ \\
8 & $23^{\circ} 46.1$ & $90^{\circ} 25.4$ & $24.95 \mathrm{v}$ & $42.74 \mathrm{~m}$ & $70.00 \mathrm{p}$ & $143.00 \mathrm{r}$ \\
9 & $23^{\circ} 46.1$ & $90^{\circ} 24.9$ & $10.06 \mathrm{~m}$ & $19.04 \mathrm{li}$ & $35.00 \mathrm{~h}$ & $76.00 \mathrm{i}$ \\
10 & $23^{\circ} 45.9$ & $90^{\circ} 24.8$ & $7.57 \mathrm{j}$ & $16.57 \mathrm{gh}$ & $30.00 \mathrm{~g}$ & $135.00 \mathrm{p}$ \\
11 & $23^{\circ} 45.7$ & $90^{\circ} 24.4$ & $6.55 \mathrm{i}$ & $9.39 \mathrm{bcd}$ & $28.00 \mathrm{f}$ & $143.50 \mathrm{~s}$ \\
12 & $23^{\circ} 45.7$ & $90^{\circ} 27.8$ & 9.661 & $27.10 \mathrm{k}$ & $45.00 \mathrm{k}$ & 100.001 \\
13 & $23^{\circ} 45.7$ & $90^{\circ} 27.9$ & $11.00 \mathrm{n}$ & $14.00 \mathrm{efg}$ & $28.00 \mathrm{f}$ & $56.00 \mathrm{e}$ \\
14 & $23^{\circ} 45.7$ & $90^{\circ} 28.1$ & $1.84 \mathrm{a}$ & $2.87 \mathrm{a}$ & $6.10 \mathrm{a}$ & $11.00 \mathrm{a}$ \\
15 & $23^{\circ} 45.7$ & $90^{\circ} 28.4$ & $12.77 \mathrm{p}$ & $24.63 \mathrm{jk}$ & $43.00 \mathrm{j}$ & $87.00 \mathrm{j}$ \\
16 & $23^{\circ} 45.6$ & $90^{\circ} 28.7$ & $11.00 \mathrm{n}$ & $12.00 \mathrm{def}$ & $24.00 \mathrm{e}$ & $73.00 \mathrm{~h}$ \\
17 & $23^{\circ} 45.6$ & $90^{\circ} 28.7$ & $3.58 \mathrm{~d}$ & $8.53 \mathrm{bcd}$ & $14.00 \mathrm{~d}$ & $60.00 \mathrm{f}$ \\
18 & $23^{\circ} 46.6$ & $90^{\circ} 28.9$ & $2.63 \mathrm{~b}$ & $6.47 \mathrm{abc}$ & $12.00 \mathrm{c}$ & $45.00 \mathrm{~d}$ \\
19 & $23^{\circ} 45.5$ & $90^{\circ} 28.9$ & $3.36 \mathrm{c}$ & $5.67 \mathrm{ab}$ & $11.00 \mathrm{~b}$ & $31.00 \mathrm{c}$ \\
20 & $23^{\circ} 45.9$ & $90^{\circ} 27.8$ & $3.99 \mathrm{e}$ & $5.72 \mathrm{ab}$ & $12.00 \mathrm{c}$ & $29.00 \mathrm{~b}$ \\
21 & $23^{\circ} 45.6$ & $90^{\circ} 27.5$ & $5.87 \mathrm{f}$ & $15.42 \mathrm{fgh}$ & $24.00 \mathrm{e}$ & $76.00 \mathrm{i}$ \\
22 & $23^{\circ} 45.6$ & $90^{\circ} 27.2$ & $6.30 \mathrm{~h}$ & $16.50 \mathrm{gh}$ & $45.00 \mathrm{k}$ & $72.00 \mathrm{~g}$ \\
23 & $23^{\circ} 46.6$ & $90^{\circ} 26.8$ & $6.23 \mathrm{~g}$ & $10.42 \mathrm{cde}$ & $55.00 \mathrm{n}$ & $87.00 \mathrm{j}$ \\
24 & $23^{\circ} 45.7$ & $90^{\circ} 26.5$ & $7.96 \mathrm{k}$ & $8.30 \mathrm{bcd}$ & $59.00 \mathrm{o}$ & $98.00 \mathrm{k}$ \\
Max & & & 55.00 & 109.91 & 213.00 \\
Min & & & 1.84 .35 & 2.87 & 6.10 & 11.00 \\
Mean & & & 11.42 & 20.27 & 40.33 & 95.08 \\
\hline
\end{tabular}

Mean values with the same letter (s) in a column is not significantly different at $5 \%$ level by Duncan's Multiple Range Test (DMRT).

water soluble fraction which might be due to flooding or dilution effect during wet season.

The $\mathrm{Pb}$ concentration decreased from point source (location 1) to successive locations in all respect but total $\mathrm{Pb}$ concentration in most of the cases were found to be above the tolerable limit value (Kloke, 1980).

Water soluble lead concentrations in different sampling points were significantly different from each other except some sampling points. The lowest concentration of water soluble $\mathrm{Pb}$ was found in the sampling point 14 . On the other hand the highest concentration of water soluble $\mathrm{Pb}$ was found at the source point 1 .
$\mathrm{NH}_{4} \mathrm{OAc}$ and DTPA extractable $\mathrm{Pb}$ concentration at different sampling points were significantly different from each other. The lowest concentration of $\mathrm{NH}_{4} \mathrm{OAc}$ extractable and DTPA extractable $\mathrm{Pb}$ was found at the sampling point 14 and the highest was found in the sampling point 1 i.e. at the source point.

In case of total $\mathrm{Pb}$ concentration in soil, the lowest value was in point 14 and the highest was in the sampling point 1 which was above the tolerable limit value (Kloke, 1980). Total lead concentration in 24 sampling points differed significantly from each other except some points (Table III). Total $\mathrm{Pb}$ concentrations at some sampling points were above 
Table III: Concentration of $\mathrm{Pb}$ in soils with different extractant during $2 \mathrm{nd}$ sampling

\begin{tabular}{|c|c|c|c|c|c|c|}
\hline \multirow[t]{2}{*}{ Location } & \multirow[t]{2}{*}{$\begin{array}{l}\text { Longitude, } \\
\text { North }\end{array}$} & \multirow[t]{2}{*}{$\begin{array}{l}\text { Latitude } \\
\text { East }\end{array}$} & $\begin{array}{c}\text { Water } \\
\text { soluble } \mathrm{Pb}\end{array}$ & $\begin{array}{c}\mathrm{NH}_{4} \mathrm{Oc} \\
\text { Exchbngeble PB }\end{array}$ & $\begin{array}{c}\text { DTPA } \\
\text { Extractable } \mathrm{Pb}\end{array}$ & $\begin{array}{l}\text { Total } \mathrm{Pb} \text { by } \\
\text { Aqua-regia }\end{array}$ \\
\hline & & & \multicolumn{4}{|c|}{$\mathrm{mg} \mathrm{kg}^{-1}$} \\
\hline 1 & $23^{\circ} 45.7$ & $90^{\circ} 24.5$ & $27.48 \mathrm{c}$ & $47.17 \mathrm{c}$ & $101.6 \mathrm{c}$ & $222.2 \mathrm{e}$ \\
\hline 2 & $23^{\circ} 45.8$ & $90^{\circ} 24.6$ & $16.73 \mathrm{abc}$ & $31.41 \mathrm{bc}$ & $62.04 \mathrm{bc}$ & $145.86 \mathrm{~cd}$ \\
\hline 3 & $23^{\circ} 46.0$ & $90^{\circ} 24.7$ & $21.15 \mathrm{bc}$ & $29.45 \mathrm{abc}$ & $70.40 \mathrm{bc}$ & $150.48 \mathrm{~cd}$ \\
\hline 4 & $23^{\circ} 46.2$ & $90^{\circ} 24.8$ & $9.18 \mathrm{ab}$ & $18.02 \mathrm{ab}$ & $45.32 \mathrm{ab}$ & $166.54 \mathrm{de}$ \\
\hline 5 & $23^{\circ} 46.3$ & $90^{\circ} 24.9$ & $11.76 \mathrm{ab}$ & $19.14 \mathrm{ab}$ & $41.80 \mathrm{ab}$ & $94.04 \mathrm{abc}$ \\
\hline 6 & $23^{\circ} 46.2$ & $90^{\circ} 25.0$ & $3.23 \mathrm{a}$ & $7.31 \mathrm{a}$ & $16.28 \mathrm{a}$ & $59.84 \mathrm{a}$ \\
\hline 7 & $23^{\circ} 46.1$ & $90^{\circ} 25.1$ & $5.43 \mathrm{a}$ & $12.74 \mathrm{ab}$ & $35.64 \mathrm{ab}$ & $77.88 \mathrm{ab}$ \\
\hline 8 & $23^{\circ} 46.1$ & $90^{\circ} 25.4$ & $7.59 \mathrm{ab}$ & $9.55 \mathrm{ab}$ & $76.12 \mathrm{bc}$ & $124.54 \mathrm{bcd}$ \\
\hline 9 & $23^{\circ} 46.1$ & $90^{\circ} 24.9$ & $27.46 \mathrm{c}$ & $47.17 \mathrm{c}$ & $101.59 \mathrm{bc}$ & 222.19 e \\
\hline 10 & $23^{\circ} 45.9$ & $90^{\circ} 24.8$ & $16.71 \mathrm{abc}$ & $31.41 \mathrm{bc}$ & $62.03 \mathrm{bc}$ & $145.85 \mathrm{~cd}$ \\
\hline 11 & $23^{\circ} 45.7$ & $90^{\circ} 24.4$ & $21.14 \mathrm{bc}$ & $29.44 \mathrm{abc}$ & $70.39 \mathrm{bc}$ & $150.47 \mathrm{~cd}$ \\
\hline 12 & $23^{\circ} 45.7$ & $90^{\circ} 27.8$ & $9.14 \mathrm{ab}$ & $18.07 \mathrm{ab}$ & $45.31 \mathrm{ab}$ & $166.53 \mathrm{de}$ \\
\hline 13 & $23^{\circ} 45.7$ & $90^{\circ} 27.9$ & $11.75 \mathrm{ab}$ & $19.13 \mathrm{ab}$ & $41.79 \mathrm{ab}$ & $95.03 \mathrm{abc}$ \\
\hline 14 & $23^{\circ} 45.7$ & $90^{\circ} 28.1$ & $3.21 \mathrm{a}$ & $7.30 \mathrm{a}$ & $16.26 \mathrm{a}$ & 59.83 a \\
\hline 15 & $23^{\circ} 45.7$ & $90^{\circ} 28.4$ & $5.41 \mathrm{a}$ & $12.73 \mathrm{ab}$ & $35.63 \mathrm{ab}$ & $77.87 \mathrm{ab}$ \\
\hline 16 & $23^{\circ} 45.6$ & $90^{\circ} 28.7$ & $7.58 \mathrm{ab}$ & $9.54 \mathrm{ab}$ & $76.11 \mathrm{bc}$ & $124.51 \mathrm{bcd}$ \\
\hline 17 & $23^{\circ} 45.6$ & $90^{\circ} 28.7$ & $27.39 \mathrm{c}$ & $47.18 \mathrm{c}$ & $101.61 \mathrm{c}$ & $222.21 \mathrm{e}$ \\
\hline 18 & $23^{\circ} 46.6$ & $90^{\circ} 28.9$ & $16.73 \mathrm{abc}$ & $31.42 \mathrm{bc}$ & $62.05 \mathrm{bc}$ & $145.87 \mathrm{~cd}$ \\
\hline 19 & $23^{\circ} 45.5$ & $90^{\circ} 28.9$ & $21.16 \mathrm{bc}$ & $29.46 \mathrm{abc}$ & $70.41 \mathrm{bc}$ & $150.49 \mathrm{~cd}$ \\
\hline 20 & $23^{\circ} 45.9$ & $90^{\circ} 27.8$ & $9.19 \mathrm{ab}$ & $18.03 \mathrm{ab}$ & $45.33 \mathrm{ab}$ & $166.54 \mathrm{de}$ \\
\hline 21 & $23^{\circ} 45.6$ & $90^{\circ} 27.5$ & $11.77 \mathrm{ab}$ & $19.15 \mathrm{ab}$ & $41.41 \mathrm{ab}$ & $95.05 \mathrm{abc}$ \\
\hline 22 & $23^{\circ} 45.6$ & $90^{\circ} 27.2$ & $3.23 \mathrm{a}$ & $7.32 \mathrm{a}$ & $16.29 \mathrm{a}$ & $59.85 \mathrm{a}$ \\
\hline 23 & $23^{\circ} 46.6$ & $90^{\circ} 26.8$ & $5.43 \mathrm{a}$ & $12.75 \mathrm{ab}$ & $30.65 \mathrm{ab}$ & $77.89 \mathrm{ab}$ \\
\hline 24 & $23^{\circ} 45.7$ & $90^{\circ} 26.5$ & $7.60 \mathrm{ab}$ & $9.56 \mathrm{ab}$ & $76.133 \mathrm{bc}$ & $124.53 \mathrm{bcd}$ \\
\hline Max & & & 27.48 & 47.18 & 101.61 & 222.21 \\
\hline Min & & & 3.21 & 7.30 & 16.26 & 59.83 \\
\hline Mean & & & 7.80 & 21.85 & 56.15 & 130.29 \\
\hline
\end{tabular}

Mean values followed by the same letter (s) within the column is not significantly different at the 5\% level by DMRT.

the maximum tolerable limit $\left(100 \mathrm{mg} \mathrm{kg}^{-1}\right)$ according to Kloke (1980).

As a whole, the Tejgaon industrial area soils, had the highest concentration of total, water soluble, $\mathrm{NH}_{4} \mathrm{OAc}$ extractable and DTPA extractable $\mathrm{Pb}$ in some points which might be due to discharge of liquid wastes, flocculated sludge and other solids with excessive metals coming from different industrial processes. The highest concentration of $\mathrm{Pb}$ and other metals in this area is not only a problem with respect to plant nutrition and the food chain, but also a direct health hazard because of its carcinogenic characteristics. The area is not only occupied by industries but also inhabited by many slums people around the complexes and on the bank of waste discharging channel. Recently many urban area/housing projects namely, Aftab Nagar, Bansree housing project, Niketon project etc. have developed on the bank of waste discharging channel. So, these may be ecological implications associated with metal poisoning to the slum living children because they have direct contact with the contaminated soil and effluents (Thornton et al., 1985). The highest concentration of total and extractable $\mathrm{Pb}$, is also due to effluents and solid wastes of textile dying industry.

Water soluble, $\mathrm{NH}_{4} \mathrm{OAc}$ extractable and DTPA extractable $\mathrm{Pb}$ have been considered as available $\mathrm{Pb}$ (Lindsay and 
Norvell, 1978). The sum of these $\mathrm{Pb}$ species is a measure of available concentration of $\mathrm{Pb}$ in the contaminated soils of Tejgaon industrial area. Considering the critical limits of DTPA-extractant for Pb (Lindsay and Norvell, 1978), some of the sampling points were above the critical limits. The concentration of $\mathrm{Pb}$ in the soil solution phase strongly increased with decreasing $\mathrm{pH}$ and increasing total content of this metal in the different sampling points. The similar results were also reported by many authors (Chamon et al., 2005, Nuruzzaman et al., 1995, Mondol et al., 2002).

\section{Water samples}

From the 1st sampling water data (wet season) TSS and TDS values were much above the maximum standards of water quality (data not given here) (CPCB, 1995; DOE, 1992). BOD, COD and DO values were much lower than the minimum standards of water quality (data not given here) (CPCB, 1995; DOE, 1992). The general water quality of the whole study area was extremely poor. Foul smell was so intense that some of the workers had to abandon the sampling protocol.

Table IV : Concentration of $\mathrm{Pb}$ in water samples brought during 1st and 2nd sampling

\begin{tabular}{|c|c|c|c|c|}
\hline \multirow[t]{2}{*}{$\begin{array}{l}\text { Sampling } \\
\text { Location }\end{array}$} & \multirow[t]{2}{*}{$\begin{array}{c}\text { Longitude, } \\
\text { North }\end{array}$} & \multirow{2}{*}{$\begin{array}{l}\text { Latitude } \\
\text { East }\end{array}$} & 1st sampling & $\begin{array}{c}\text { 2nd } \\
\text { sampling }\end{array}$ \\
\hline & & & \multicolumn{2}{|c|}{$\mathrm{mg} \mathrm{kg}^{-1}$} \\
\hline 1 & $23^{\circ} 45.7$ & $90^{\circ} 24.5$ & $1.469 \mathrm{a}$ & nd \\
\hline 2 & $23^{\circ} 45.8$ & $90^{\circ} 24.6$ & $1.423 \mathrm{~b}$ & nd \\
\hline 3 & $23^{\circ} 46.0$ & $90^{\circ} 24.7$ & $1.374 \mathrm{c}$ & nd \\
\hline 4 & $23^{\circ} 46.2$ & $90^{\circ} 24.8$ & $1.285 \mathrm{~d}$ & nd \\
\hline 5 & $23^{\circ} 46.3$ & $90^{\circ} 24.9$ & $1.219 \mathrm{e}$ & nd \\
\hline 6 & $23^{\circ} 46.2$ & $90^{\circ} 25.0$ & $0.845 \mathrm{f}$ & nd \\
\hline 7 & $23^{\circ} 46.1$ & $90^{\circ} 25.4$ & $0.85 \mathrm{~g}$ & nd \\
\hline 8 & $23^{\circ} 46.1$ & $90^{\circ} 24.9$ & $0.802 \mathrm{~h}$ & nd \\
\hline 9 & $23^{\circ} 45.9$ & $90^{\circ} 24.8$ & $0.753 \mathrm{i}$ & nd \\
\hline 10 & $23^{\circ} 45.6$ & $90^{\circ} 24.6$ & $0.681 \mathrm{j}$ & nd \\
\hline 11 & $23^{\circ} 45.7$ & $90^{\circ} 24.4$ & $0.595 \mathrm{k}$ & nd \\
\hline 12 & $23^{\circ} 45.7$ & $90^{\circ} 27.8$ & 0.5091 & nd \\
\hline 13 & $23^{\circ} 45.7$ & $90^{\circ} 27.8$ & $0.452 \mathrm{n}$ & nd \\
\hline 14 & $23^{\circ} 45.7$ & $90^{\circ} 27.9$ & $0.402 \mathrm{~m}$ & nd \\
\hline 15 & $23^{\circ} 45.7$ & $90^{\circ} 28.1$ & 0.336 o & nd \\
\hline 16 & $23^{\circ} 45.7$ & $90^{\circ} 28.4$ & $0.269 \mathrm{p}$ & nd \\
\hline 17 & $23^{\circ} 45.6$ & $90^{\circ} 28.7$ & $0.232 \mathrm{q}$ & nd \\
\hline 18 & $23^{\circ} 45.6$ & $90^{\circ} 28.7$ & $0.153 \mathrm{r}$ & nd \\
\hline 19 & $23^{\circ} 46.6$ & $90^{\circ} 28.9$ & $0.06 \mathrm{~s}$ & nd \\
\hline 20 & $23^{\circ} 45.5$ & $90^{\circ} 28.9$ & $0.04 \mathrm{~s}$ & nd \\
\hline 21 & $23^{\circ} 45.55$ & $90^{\circ} 29.0$ & $0.133 \mathrm{t}$ & nd \\
\hline 22 & $23^{\circ} 45.9$ & $90^{\circ} 27.8$ & $0.212 \mathrm{u}$ & nd \\
\hline 23 & $23^{\circ} 45.6$ & $90^{\circ} 27.5$ & $0.249 \mathrm{v}$ & nd \\
\hline 24 & $23^{\circ} 45.6$ & $90^{\circ} 27.2$ & $0.223 \mathrm{w}$ & nd \\
\hline 25 & $23^{\circ} 46.6$ & $90^{\circ} 26.8$ & $0.316 x$ & nd \\
\hline 26 & $23^{\circ} 45.7$ & $90^{\circ} 26.5$ & $0.382 \mathrm{y}$ & nd \\
\hline 27 & $23^{\circ} 45.8$ & $90^{\circ} 26.2$ & $0.432 \mathrm{z}$ & nd \\
\hline 28 & $23^{\circ} 45.8$ & $90^{\circ} 25.9$ & $0.489 \mathrm{a}$ & nd \\
\hline 29 & $23^{\circ} 46.0$ & $90^{\circ} 25.6$ & $0.575 \mathrm{~b}$ & nd \\
\hline mean & & & 0.661 & \\
\hline
\end{tabular}

nd= not done

Mean values with the same letter (s) in a column is not significantly different at 5\% level by DMRT. 
The concentration of $\mathrm{Pb}$ in water sample during rainy season ranges from 0.04 to $1.469 \mathrm{mg} \mathrm{L}^{-1}$ (Table IV). The average concentration was 0.661 which was much above the tolerable drinking water standard according to WHO (2004) (Table V). Ullah et al. (1995) investigated heavy metal pollution of soils and water and their transfer into plants in Bangladesh. According to Ullah et al. (1996) and Chamon et al. (2005), Tejgaon industrial area was polluted with $\mathrm{Ni}, \mathrm{Pb}$ and $\mathrm{Cd}$.

\section{Plant samples}

Heavy metal concentration in plant samples was high at the study area. Plant samples accumulated more and tolerated higher amounts of heavy metals as reported by Chamon et al. (2005).

Average total concentration of $\mathrm{Pb}$ were 19.65 and $19.83 \mathrm{mg}$ $\mathrm{kg}^{-1}$ respectively (Table $\mathrm{V}$ ), during wet and dry season, at Tejgaon industrial area which were in the range of plants general toxic concentration level (Sauerbeck, 1982 ).

Table V: Concentration of $\mathrm{Pb}$ in plant samples brought during wet and dry season

\begin{tabular}{|c|c|c|c|c|c|}
\hline \multirow{3}{*}{$\begin{array}{l}\text { Sampling } \\
\text { Location }\end{array}$} & \multicolumn{5}{|c|}{ Plant samples } \\
\hline & \multirow{2}{*}{$\begin{array}{c}\text { Longitude, } \\
\text { North }\end{array}$} & \multirow{2}{*}{$\begin{array}{c}\text { Latitude } \\
\text { East }\end{array}$} & \multirow{2}{*}{ Sample type } & Wet season & Dry season \\
\hline & & & & \multicolumn{2}{|c|}{$\mathrm{mg} \mathrm{kg}^{-1}$} \\
\hline 1 & $23^{\circ} 45.7$ & $90^{\circ} 24.5$ & Grass & $19.53 \mathrm{abc}$ & $20.58 \mathrm{~b}$ \\
\hline 2 & $23^{\circ} 45.8$ & $90^{\circ} 24.6$ & Bean leaf & $14.60 \mathrm{a}$ & $20.87 \mathrm{ab}$ \\
\hline 3 & $23^{\circ} 46.0$ & $90^{\circ} 24.7$ & Grass & $17.60 \mathrm{ab}$ & $22.57 \mathrm{~b}$ \\
\hline 4 & $23^{\circ} 46.2$ & $90^{\circ} 24.8$ & Grass & $19.13 \mathrm{abc}$ & $17.5 \mathrm{a}$ \\
\hline 5 & $23^{\circ} 46.3$ & $90^{\circ} 24.9$ & Grass & $17.20 \mathrm{a}$ & $20.23 \mathrm{ab}$ \\
\hline 6 & $23^{\circ} 46.2$ & $90^{\circ} 25.0$ & Grass & $18.67 \mathrm{abc}$ & $20.83 \mathrm{ab}$ \\
\hline 7 & $23^{\circ} 46.1$ & $90^{\circ} 25.1$ & Water hyacinth & $20.53 \mathrm{abc}$ & $17.57 \mathrm{a}$ \\
\hline 8 & $23^{\circ} 46.1$ & $90^{\circ} 25.4$ & Water hyacinth & $24.33 \mathrm{bc}$ & $19.53 \mathrm{ab}$ \\
\hline 9 & $23^{\circ} 46.1$ & $90^{\circ} 24.9$ & Bean leaf & $25.27 \mathrm{c}$ & $21.63 \mathrm{~b}$ \\
\hline 10 & $23^{\circ} 45.9$ & $90^{\circ} 24.8$ & Kalmi & $19.54 \mathrm{abc}$ & $17.7 \mathrm{a}$ \\
\hline 11 & $23^{\circ} 45.7$ & $90^{\circ} 27.8$ & Water hyacinth & $14.61 \mathrm{a}$ & $20.83 \mathrm{ab}$ \\
\hline 12 & $23^{\circ} 45.7$ & $90^{\circ} 27.9$ & Water hyacinth & $17.61 \mathrm{ab}$ & $20.58 \mathrm{~b}$ \\
\hline 13 & $23^{\circ} 45.7$ & $90^{\circ} 28.1$ & Bean leaf & $19.14 \mathrm{abc}$ & $17.6 \mathrm{a}$ \\
\hline 14 & $23^{\circ} 45.7$ & $90^{\circ} 28.4$ & Kalmi & $17.21 \mathrm{a}$ & $20.3 \mathrm{ab}$ \\
\hline 15 & $23^{\circ} 45.6$ & $90^{\circ} 28.7$ & Kalmi & $18.68 \mathrm{abc}$ & $20.9 \mathrm{ab}$ \\
\hline 16 & $23^{\circ} 45.6$ & $90^{\circ} 28.7$ & Water hyacinth & $20.54 \mathrm{abc}$ & $17.6 \mathrm{a}$ \\
\hline 17 & $23^{\circ} 46.6$ & $90^{\circ} 28.9$ & Kalmi & $24.34 \mathrm{bc}$ & $19.6 \mathrm{ab}$ \\
\hline 18 & $23^{\circ} 45.5$ & $90^{\circ} 28.9$ & Kalmi & $25.28 \mathrm{c}$ & $21.7 \mathrm{~b}$ \\
\hline 19 & $23^{\circ} 45.55$ & $90^{\circ} 29.0$ & Kalmi & $19.52 \mathrm{abc}$ & $17.6 \mathrm{a}$ \\
\hline 20 & $23^{\circ} 45.9$ & $90^{\circ} 27.8$ & Water hyacinth & $14.59 \mathrm{a}$ & $20.77 \mathrm{ab}$ \\
\hline 21 & $23^{\circ} 45.6$ & $90^{\circ} 27.5$ & Water hyacinth & $17.59 \mathrm{ab}$ & $22.44 \mathrm{~b}$ \\
\hline 22 & $23^{\circ} 45.6$ & $90^{\circ} 27.2$ & Water hyacinth & $19.12 \mathrm{abc}$ & $17.4 \mathrm{a}$ \\
\hline 23 & $23^{\circ} 46.6$ & $90^{\circ} 26.8$ & Water hyacinth & $17.19 \mathrm{a}$ & $20.13 \mathrm{ab}$ \\
\hline 24 & $23^{\circ} 45.7$ & $90^{\circ} 26.5$ & Kalmi & $18.66 \mathrm{abc}$ & $20.73 \mathrm{ab}$ \\
\hline 25 & $23^{\circ} 45.8$ & $90^{\circ} 26.2$ & Water hyacinth & $20.52 \mathrm{abc}$ & $17.47 \mathrm{a}$ \\
\hline 26 & $23^{\circ} 45.8$ & $90^{\circ} 25.9$ & Water hyacinth & $24.32 \mathrm{bc}$ & $19.43 \mathrm{ab}$ \\
\hline 27 & $23^{\circ} 46.0$ & $90^{\circ} 25.6$ & Water hyacinth & $25.26 \mathrm{c}$ & $21.53 \mathrm{~b}$ \\
\hline Max & & & & 25.28 & 22.57 \\
\hline Min & & & & 14.59 & 17.4 \\
\hline Mean & & & & 19,65 & 19.83 \\
\hline
\end{tabular}

Mean values with the same letter (s) in a column is not significantly different at 5\% level by DMRT 
Metal contaminations of soils, sediments, water bodies and plants have also been reported earlier (Bharma and Costa, 1992; Ullah et al. 1995, 1999; Chamon et al., 2005 and Kashem and Singh, 1998). Concentrations of total soil $\mathrm{Pb}$ in most of the locations were found to be above the toxic level (Table II and III). During 2nd sampling Pb concentration in around $50 \%$ plant samples were higher than 1st sampling data (Table V). Pb content was above the critical limit in grass and water hyacinth in some sampling points e.g in the point $7,8,9,16,17,18,25,26 \& 27$ but low in other plant samples. During the 2nd sampling $\mathrm{Pb}$ concentrations in all plant samples, except a few, were above critical limit.

\section{Extent of contamination by $\mathrm{Pb}$ in soils, plants and water:}

Expeditions to collect samples were extremely difficult due to the foul smell and unknown nature of gases emitting out of the water body. The soil, water and air were unfit for any kind of human consumption. But a vast number of people are living and working in the area disregarding the existing severe health hazards. Results show that the soil, water and plant were of extremely low quality in the rainy season. Their quality deteriorated several fold in the dry season.

The $\mathrm{pH}$ dependence of the soluble $\mathrm{Pb}$ content show that the mobility and availability of the metal is high at strongly to extremely acid soil reaction. This was also reported by Brümmer et al., (1986).

The extent of $\mathrm{Pb}$ contamination due to heavy metal deposition in Tejgaon industrial sites are presented in Table VII. The total $\mathrm{Pb}$ content of the soils, water and plant samples showed wide range of values from background to a level considered to reflect severe contamination. The extent of

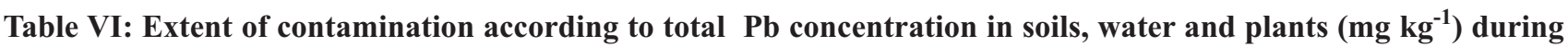
wet and dry season sampling. Percentage of sampling locations in parentheses

\begin{tabular}{|c|c|c|c|c|}
\hline Metals & & Group 1 & Group 2 & Group 3 \\
\hline \multicolumn{5}{|l|}{ Soil $(n=24)$} \\
\hline \multirow{4}{*}{$\mathrm{Pb}$ (wet season) } & Water soluble & $\leq 20(87.5)$ & $>20-\leq 100(12.5)$ & $\geq 100(0)$ \\
\hline & $\mathrm{NH}_{4} \mathrm{OAc}$ & $\leq 20(58)$ & $>20-\leq 100(42)$ & $\geq 100(0)$ \\
\hline & DTPA & $\leq 20(21)$ & $>20-\leq 100(75)$ & $\geq 100(4)$ \\
\hline & Total & $\leq 20(4)$ & $>20-\leq 100(58)$ & $\geq 100(38)$ \\
\hline \multirow{4}{*}{$\mathrm{Pb}$ (dry season) } & Water soluble & $\leq 20(75)$ & $>20-\leq 100(25)$ & $\geq 100((0)$ \\
\hline & $\mathrm{NH}_{4} \mathrm{OAc}$ & $\leq 20(62)$ & $>20-\leq 100$ & $\geq 100(0)$ \\
\hline & DTPA & $\leq 20(12.5)$ & $>20-\leq 100(75)$ & $\geq 100(12.5)$ \\
\hline & Total & $\leq 20(0)$ & $>20-\leq 100(37.5)$ & $\geq 100(62.5)$ \\
\hline \multicolumn{5}{|l|}{ Water $(n=29)$} \\
\hline \multirow{2}{*}{\multicolumn{2}{|c|}{$\begin{array}{l}\mathrm{Pb} \text { (wet season) } \\
\mathrm{Pb} \text { (dry season) }\end{array}$}} & $0.00-<0.01(0)$ & $0.01(0)$ & $>0.01(100)$ \\
\hline & & nd & nd & nd \\
\hline \multicolumn{5}{|l|}{ Plant $(n=27)$} \\
\hline \multicolumn{2}{|c|}{$\mathrm{Pb}$ (wet season) } & $0-<10(0)$ & $>10-\leq 20(67)$ & $>20(33)$ \\
\hline \multicolumn{2}{|c|}{$\mathrm{Pb}$ (dry season) } & $0-<10(0)$ & $>10-\leq 20(41)$ & $>20(59)$ \\
\hline
\end{tabular}

Group 1 = Background level, group 2= Maximum tolerable level and group $3=$ In excess of tolerable level.

Soil

Background concentration for $\mathrm{Pb}=12-20 \mathrm{mg} \mathrm{kg}^{-1}$ (Singh and Steinnes, 1994) of Bangladesh soil. Tolerable total concentrations is $100 \mathrm{mg} \mathrm{kg}^{-1}$ for $\mathrm{Pb}$ (Kloke, 1980).

\section{Water}

Background concentration for $\mathrm{Pb}=0.00-<0.01 \mathrm{mg} \mathrm{L}^{-1} \mathrm{ppm}$ of drinking water of Bangladesh, (WHO, 2004). Tolerable total concentrations is $>0.01 \mathrm{ppm}$ for $\mathrm{Pb}$ (WHO, 2004).

\section{Plant}

Background concentration for $\mathrm{Pb}=0-<10 \mathrm{mg} \mathrm{kg}^{-1}$ (Sauerbeck, 1982). Toxic concentrations is $10-20 \mathrm{mg} \mathrm{kg}^{-1}$ for $\mathrm{Pb}$ (Sauerbeck, 1982). 
contamination (in \%) was identified by using information of background levels of total $\mathrm{Pb}$ in soils (Singh and Steinnes, 1994) and background levels of $\mathrm{Pb}$ for Bangladesh soils (Domingo and Kyrzma,1983). The tolerable and in excess of tolerable level was calculated on the information of Kloke (1980).

Background concentration for $\mathrm{Pb}$ of Bangladeshi soils is 20 $\mathrm{mg} \mathrm{kg}^{-1}$ (Domingo and Kyuma, 1983). Tolerable total concentration of $\mathrm{Pb}$ in soil is $100 \mathrm{mg} \mathrm{kg}-1$ (Kloke, 1980). The total $\mathrm{Pb}$ concentration of the soil samples at different points showed wide range of values from background to a level considered to reflect severe contamination. The extent of contamination was identified by using information of background levels of total $\mathrm{Pb}$ in soils (Domingo and Kyruma, 1983; Singh and Steinnes, 1994; Nuruzzaman et al. 1995; Ullah et al. 1999 and Chamon et al. 2005). The tolerable and in excess of tolerable level was calculated on the information of Kloke (1980).

Concentrations of total $\mathrm{Pb}$ in soils during 1st sampling were found above the natural background level with few exceptions. Only $4 \%$ samples contained total $\mathrm{Pb}$ in the normal range $\left(=20 \mathrm{mg} \mathrm{kg}^{-1}\right)$. Total $\mathrm{Pb}$ concentration in the group of tolerable level was $58 \%\left(>0.220=100 \mathrm{mg} \mathrm{kg}^{-1}\right)$ and $38 \%$ $\left(=100 \mathrm{mg} \mathrm{kg}^{-1}\right)$ soil samples were found in the group of in excess of tolerable level. In case of dry season no soil sample was found to contain $\mathrm{Pb}$ in the normal range $(=20 \mathrm{mg}$ $\left.\mathrm{kg}^{-1}\right)$. Total $\mathrm{Pb}$ concentration in the group of tolerable level $\left(>0.220=100 \mathrm{mg} \mathrm{kg}^{-1}\right)$ was $37 \%$ and $63 \%$ soil samples were found in the group of in excess of tolerable level ( $=100$ $\left.\mathrm{mg} \mathrm{kg}^{-1}\right)$. Different solvent extractable $\mathrm{Pb}$ concentrations were also found variable at successive sampling locations as shown in table II and III.

In case of water samples, $\mathrm{Pb}$ concentration in the rainy season, all samples were found in the group of in excess of tolerable level $\left(>0.01 \mathrm{mg} \mathrm{L}^{-1}\right)$ (Table VI).

During 1st sampling period, rainy season saw dilution of water due to influx of rain water and floodwater from surrounding areas. Fresh water diluted and washed away much of the pollutants. But it was not enough to completely wash pollutants away. As water receded and pollution load increased with dry season (2nd sampling period), heavy metals concentration increased 2 to 3 times compared to rainy season (Ullah et al., 1999).

Plants take up heavy metals from solution without any hindrance. During the rainy season most plants were grass and water hyacinth with a few other plants. Most of the grasses and water hyacinth find their way into the food chain in the form of cattle feed. During the dry season rice, grass and many other types of 'rabi' crops, e.g., tomato, capsicum, cabbage, cauliflower, etc. were growing in the contaminated soils irrigated with these polluted water. $\mathrm{Pb}$ concentrations were very high and above critical level in all crop plants in both seasons. 33 and $59 \%$ of plant samples were found in the group of in excess of tolerable level during wet and dry season, respectively (Table VII).

One of the most alarming facts is that some sampling points under investigation were apparently more polluted than sampling point near pollution source. Bumper crops were being produced in the vicinity of Balu river. Locally produced crops with attractive appearances may have high $\mathrm{Pb}$ content.

Concentrations of heavy metals such as $\mathrm{Pb}$ was much higher in grass and water hyacinth in the Tejgaon industrial area and it may be due to the exposure of these plants to heavy metals for a longer period or there might be different mechanism of absorption of heavy metals by these plants. Elevated levels of $\mathrm{Cd}, \mathrm{Cu}, \mathrm{Pb}$ and $\mathrm{Zn}$ in plants in this area have been demonstrated by other investigators (Kashem and Singh, 1998; Ullah et al., 1999; Mondol et al., 2002; Chamon et al., 2005).

\section{Distribution of total $\left(\mathrm{HNO}_{3}{ }^{-} \mathrm{HCl}\right) \mathrm{Pb}$ with distance}

Distribution of water soluble, $\mathrm{NH}_{4} \mathrm{OAc}$ extractable, DTPA extractable and total lead content in the soils of Tejgaon Industrial area during wet and dry season are presented in Fig. 1 and 2. The $\mathrm{Pb}$ concentrations in soils with different extractant were found to decrease with distance away from the disposal point due to dilution of the effluent and water. Similar findings were also observed by other investigators. Freedman and Hutchinson (1980) and Blom (1986) reported a very drastic decrease in metal concentration away from the source point i.e from an electro-metallic industry in southeastern Norway. The decreasing tendency with distance indicates the accumulation of metals by these industrial operations. The Tejgaon industrial area is low-lying and wet through most part of the year. This part is influenced by the battery, biscuit, paper and pulps, textiles, carbides, pharmaceuticals, pesticides, distilleries etc, where all effluents and wastes converge and the zone under investigation is designated as the confluence zone. Waste effluents discharged by these industries heavy metal concentration in environmental samples in this area. Low $\mathrm{pH}$ values in the respective sites could possibly increase solubility and mobility of metals in the soils. Increased solubility of metals is likely to lead to 


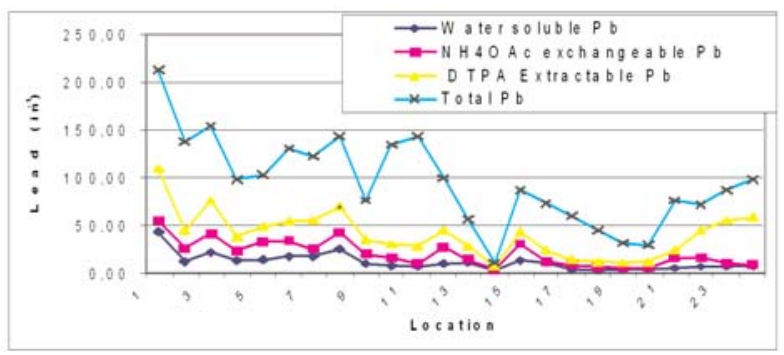

Fig. 1: Distribution of $\mathrm{Pb}$ in different fractions with distance (not to the scale) during wet season

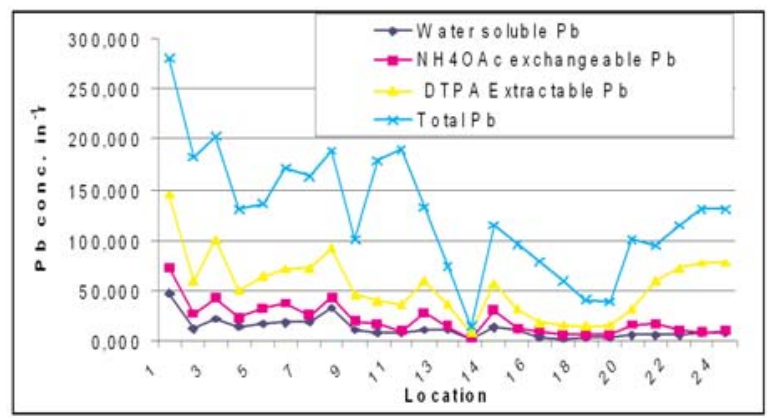

Fig. 2: Distribution of $\mathrm{Pb}$ in different fractions with distance (not to the scale) during dry season

increased availability of the metals for plant uptake, and it might cause $\mathrm{Pb}$ toxicity. This results indicate that appreciable soil acidification has taken place in the vicinity of that area. This is in agreement with the result from other investigators (Kashem and Singh, 1998; Mondol et. al., 2002; Chamon et al., 2005).

Interrelationships among the water soluble, $\mathrm{NH}_{4} \mathrm{OAc}$ extractable, DTPA extractable and total $\mathrm{Pb}$ in the Tejgaon industrial soils during wet and dry season

A correlation matrix for $\mathrm{Pb}$ metal in the soils of Tejgaon industrial sites was calculated to see if some of the $\mathrm{Pb}$ fractions were interrelated with each other and the results are presented in Table VIII and IX.

A number of fractions were observed to be significantly $(\mathrm{p}<0.01)$ correlated with each other. For example, water soluble fraction of $\mathrm{Pb}$ species was positively and significantly correlated with all other species of $\mathrm{Pb}$. The total contents of $\mathrm{Pb}$ were found to be highly correlated with their extractable amounts.

Soil $\mathrm{NH}_{4} \mathrm{OAc}$ and DTPA extractable species of $\mathrm{Pb}$ were found to be significantly correlated with other species of $\mathrm{Pb}$ during both wet and dry season (Table VII and VIII). Correlation between $\mathrm{Pb}$ content in soil and plant is insignificant.
Table VII: Descriptive statistics and Correlation matrix for different lead extractable species in soil and their correlation with plant $\mathrm{Pb}$ during wet season $(n=24)$

Descriptive Statistics

\begin{tabular}{l|c|c}
\hline & Mean & Std. Deviation \\
\hline Water soluble & 11.4233 & 9.05762 \\
NH$_{4}$ OAc & 20.0354 & 13.47697 \\
DTPA & 40.3338 & 24.15164 \\
Total & 95.0833 & 46.74228 \\
Plant & 19.1867 & 3.05353 \\
\hline
\end{tabular}

Correlations

\begin{tabular}{|c|c|c|c|c|c|}
\hline & $\begin{array}{c}\text { Water } \\
\text { soluble }\end{array}$ & $\mathrm{NH}_{4} \mathrm{OAc}$ & DTPA & Total & Plant \\
\hline $\begin{array}{l}\text { Water- } \\
\text { soluble }\end{array}$ & 1 & $922(* *)$ & $886(* *)$ & $.808(* *)$ & .087 \\
\hline $\mathrm{NH}_{4} \mathrm{OAc}$ & & 1 & $.865(* *)$ & $.816(* *)$ & .049 \\
\hline DTPA & & & 1 & $.845(* *)$ & -.029 \\
\hline Total & & & & 1 & -.106 \\
\hline Plant & & & & & 1 \\
\hline
\end{tabular}

** Correlation is significant at the 0.01 level (2-tailed).

Table VIII: Descriptive statistics and Correlation matrix for different lead extractable species in soil and their correlation with plant $\mathrm{Pb}$ during dry season $(\mathrm{n}=\mathbf{2 4})$

Descriptive Statistics

\begin{tabular}{l|c|c}
\hline & Mean & Std. Deviation \\
\hline Water soluble & 12.8117 & 7.97006 \\
$\mathrm{NH}_{4} \mathrm{OAc}$ & 21.8521 & 12.80986 \\
DTPA & 55.9413 & 25.82297 \\
Total & 130.2529 & 50.33067 \\
Plant & 19.8804 & 1.67106 \\
\hline
\end{tabular}

\section{Correlations}

\begin{tabular}{l|c|c|c|c|c}
\hline & $\begin{array}{c}\text { Water } \\
\text { soluble }\end{array}$ & $\mathrm{NH}_{4} \mathrm{OAd}$ & DTPA & Total & Plant \\
\hline Water- & & & & & \\
soluble & 1 & $.970(* *)$ & $.826(* *)$ & $.837(* *)$ & .245 \\
$\mathrm{NH}_{4} \mathrm{OAc}$ & & 1 & $.762(* *)$ & $.842(* *)$ & .243 \\
DTPA & & & 1 & $.856(* *)$ & .150 \\
Total & & & & 1 & .169 \\
Plant & & & & & 1 \\
\hline
\end{tabular}

** Correlation is significant at the 0.01 level (2-tailed). 


\section{Correlation between lead metal species in soil and in Plants}

Mean, standard deviation and correlations (r) in plants $\mathrm{Pb}$ with different soil $\mathrm{Pb}$ species are presented in table 7 and 8 during wet and dry season.

During wet season plant $\mathrm{Pb}$ positively correlate only with water soluble and $\mathrm{NH}_{4} \mathrm{OAc}$ extractable $\mathrm{Pb}$ species and negatively correlate with DTPA and total species of $\mathrm{Pb}$ in soil.

During dry season plant $\mathrm{Pb}$ positively correlate with all species of $\mathrm{Pb}$ in soil i.e. plant $\mathrm{Pb}$ positively correlate with water soluble, $\mathrm{NH}_{4} \mathrm{OAc}$ extractable, DTPA extractable and total $\mathrm{Pb}$ species in soil (Table VIII).

The positive relationship among the soil and plant cotent metal might be a cause of $\mathrm{Pb}$ toxicities to both plants and animals through their entry into food chain (Sameni et al., 1987; Roads et al., 1989).

\section{Acknowledgement}

The authors would like to thank the Ministry of Science and Information and Communication Technology, People's Republic of Bangladesh for financial support and the Centre of Excellence, University of Dhaka for giving facilities to analyze the samples. The first author would like to thank the Chairman, Dept. of Soil, Water and Environment, University of Dhaka for supporting the successful research and for providing with library, laboratory and all other research facilities as and when required.

\section{References}

Bhamra R. K. and Costa M. (1992). Trace elements-aluminium, arsenic, cadmium, mercury, lead and nickel. In. Environmental Toxicants. Morton Limg kg-1an (ed) Publ. Co. Von Nostrend Reinhold. New York. 575-615.

Blom H. A. (1986). Heavy metal contamination of soils around the cities of Østfold county',Norway (In Norwegian). Ph. D. Thesis, Norway Agric. Uni. 87-9.

Blum W. E., Spiegel H. H. and Wenzel W. W. (1996). Bodenzutstandsinventur. Konception. Durchführung und Bewertung. Empfehlungen Zur Vereinheitlichung der Vorgangsweise in Österreich. Bundesministerium für Land und Forstwirtschaft. Wien. 2nd edition. 102.

Bruemmer G. W., Gerth J. and Herms U. (1986). Heavy metal species, mobility and availability in soils. $Z$. Pflanzenernaehr, Bodenk. 149: 382-398.
Brümmer G. W., Gerth J. and Tiller K. G. (1986). Reaction kinetics of the adsorption and desorption of $\mathrm{Ni}, \mathrm{Zn}$ and Cd by goethite: I. Adsorption and diffusion of metals. J. Soil Sci. 13: 112-123.

Chamon A. S., Blum W. E. H., Gerzabek M. H., Ullah S. M., Rahman M. and Mondol M. N. (2005). Heavy metal uptake into crops on polluted soils of Bangladesh. II.Influence of Soil amendments. J. Comm. Soil Sci. Plant Analysis. 36: 907-924.

CPCB (Central Pollution Control Board). 1995. In methods of environmental analysis of soil, plant and water. Gupta (ed). New Delhi. 22-25.

DOE (Department of Environment), (1992) Environmental Quality Standards for Bangladesh. Report. 198-211.

Domingo L. E. and Kyuma K. (1983). Soil Sci. Plant Nutr. 29: 349 .

Emmerich W. E., Lund L. J , Page A. L and Chang A. C. (1982). Solid phase forms of heavy metals in sewage sludge-treated soils. J.Environ. Quality. 11: 178-181.

Freedman B. and Hutchinson T. C. (1980) Can. J. Bot. 58: 108.

He X. T.,Traina S. J. and Logan T. J (1992). Chemical properties of municipal solid waste compost. J. Environ Quality. 21: 318-329.

Horak O. (1979). Bodenkultur. 30: 120-126.

Iwegbue C. M. A., Emuh F. N., Isirimah N. O. and Egun A. C. (2007). Fractionation, Chracterization and speciation of heavy metals in composts and compost-amended soils. African J. Biotechnology. 6(2): 067-078.

Iwegbue C. M. A., Egobueze F. and Opuene K. (2006b). Preliminary assessment of heavy metals levels of soils of an oil field in the Niger Delta. Nigeria. Intl. $J$. Environ. Sci. Technol. 3(2): 167-172.

Iwegbue C. M. A., Isirimah N. O., Igwe C. and Williams E. S. (2006c). Characteristic levels of heavy metals in soil profiles of automobile mechanic waste dumps in Nigeria. Environmentalist 26: 123-128.

Kashem M. A. and Singh B. R. (1998). Heavy metal contamination of soil and vegetation in the vicinity of industries in Bangladesh. Water, Air and Soil Pollution. 115: $347-361$. 
Kloke A. (1980). Orientierungslaten fur tolerierbare Gesamtgehalte einiger Elemente in Kulturböden. Mitteilungen der VDLUFA. Heft 1-3: 9-11.

Koivula N, Hanninen K. and Tolvanen O. (2000). Windrow composting of source separated kitchen biowaste in Finland waste management and research. 18: 16-173.

Köster W. and Merkel D. (1983). Landwirtsch. Forsch. 39: Sonderh., 245-254.

Krogmann U. (1999). Effect of season and population density on source separated waste composts. Waste management and Research. 17: 109-123.

Lake D. L., Kirk P. and Lester J. N (1984). Fractionation, Characterization, and speciation of heavy metals in sewage and sludge amended soil: A review. J. Environ. Quality. 13: 175-183.

Leita L. and Nobili M De . (1991). Water-soluble fractions of heavy metal during composting of municipal solid waste. J. Environ. Qual. 22: 857-863.

Lindsay W. and Norvell W. A. (1978). Soil. Sci. Soc. Am. J. 42: 421.

Mondol M. N., Bhuyian M. A. R, Noor S., Chamon A. S., Rahman M. and Faiz S. M. A. (2002). Growth. yield and mineral nutrition of Rice, Wheat and Lettuce grown on heavy metal polluted soil. Bangladesh $J$. Environ. Sci. 8: 60-64.

Nuruzzaman M., Gerzabek M. H. and Ullah. S. M. (1995) Studis on heavy metal and microbiological pollution of soils. sediments and water systems in and around Dhaka City. Bericht an die Österr. Akademie der Wissenschaften. ÖFZS. 1995.

Petruzzelli G. (1989). Recycling wastes in Agriculture: Heavy metal bioavailability; Agric. Ecosyst. Environ. 27: 493-503.

Roads F. M., Olson, S. M. and Manning, A. (1989). $J$. Environ. Qual. 18: 159.

Sameni A. M., Maftoun, M. and Bassiri A. (1987). J. Hort, Sci. 62: 227.

Schmidtke N. W. (1980). Trends in organic sludge utilization, Murray Moo-Young and Grahame. L. Farquhar (ed). 53-78.

Sauerbeck D. (1982) Welche Schwermetallgehalte in Pflanzen dürfen nicht überschritten werden. um
Wachstumsbeeinträchtigungen zu vermeiden? Landw. Forsch. Sonderheft 39. Kongressband. 108-129.

Sparks D. L., Page A. L., Helmke P. A., Loepert R. H, Soltanpour P. N., Tabatabai M. A., Johnston C. T. and Sumner M. E. (2001) Methods of soil analysis. 1. 2 \& 3. SSSA Book Series 5. 3rd Printing. Pub. by Soil Science Society of America, Segoe Street, Madison, WI. USA. 342-344.

Singh B. R. and Steinnes E. (1994). In R. Lal and B. Stewart (eds), Soil Processes and Water Quality, Lewis Publishers, Chelsea, Mich, 233-271.

Sposito G, Lund L. J., Chang A. C. (1982) Trace metal chemistry in arid zone field soils amended with sewage sludge I. Fractionation of $\mathrm{Ni}, \mathrm{Pb}, \mathrm{Zn}, \mathrm{Cd}$ and in solid phases. Soil Sci. Soc. Am. J. 46: 260-264.

Sridhar M. K. C. and Bammeke A. O. (1986). Heavy metal contents of some solid wastes in Ibadan, Nigeria. Water, Air and Soil Pollution. 29: 51-56.

Thornton I., Gulbard E. B., Moorcroft S., Watt J. M., Weatherly M., Thompson M. and Thomas J. F. A. (1985). Environ. Technol. Letters, Lond. 6: 137.

Ullah S. M., Nuruzzaman M. and Gerzabek M. H. (1995). Heavy metal and microbiological pollution of water and sediments by industrial wastes, effluents and slums around Dhaka city. In Tropical Limnogy. K.H. Timotius and F. Goeltenboth (eds). Publ. Satya Wacana Christian University. Salatiga, Indonesia. 179-186.

Ullah S. M., Gerzabek M. H., Mondol M. N., Rashid M. M. and Islam M. (1999). Heavy metal pollution of soils and water and their transfer into plants in Bangladesh. In. Proc. of extended Abstracts. 5th International Conference on the Biogeochemistry of Trace Elements (Wenzel. W.W.; D.C.Adriano; B.Alloway; H.E. Doner; C. Keller; N.W. Lepp; M. Mench; R. Naidu and G.M. Pierzynski. (eds) Vienna, Austria. I: 260-61

Watanable M and Kurihara K. (1982). Physico-chemical characterization of municipal solid waste composts for AgriPbltural use. Bull. Natl. Inst. Agric. Sci. ser. B 85.

WHO. (2004). Guidelines for Drinking-Water Quality. World Health Organization. Geneva. 296-460.

Received :June 02, 2008;

Accepted : Febuary 06, 2011 